\title{
Evoking Baldwin's Blues: The Experience of Dislocated Listening
}

\author{
Rashida K. Braggs Williams College
}

\begin{abstract}
"It is only in his music [...] that the Negro in America has been able to tell his story. It is a story which otherwise has yet to be told and which no American is prepared to hear," so wrote James Baldwin in "Many Thousands Gone." Throughout his career, James Baldwin returned to this incomprehension of African-American experience. He continually privileged music in his literature, crafting his own literary blues to address it. Baldwin's blues resonated even more powerfully and painfully for its emotional and geographical dislocation. In this article, Rashida K. Braggs argues that it was the combination of music, word, and migration that prompted Baldwin's own deeper understanding. Exploring her term dislocated listening, Braggs investigates how listening to music while willfully dislocated from one's cultural home prompts a deeper understanding of African-American experience. The distance disconcerts, leaving one more vulnerable, while music impels the reader, audience, and even Baldwin to identify with some harsh realities of African-American experience. Baldwin evokes the experience of dislocated listening in his life and in "Sonny's Blues." Braggs also creates an experience of dislocated listening through her video performance of Baldwin's words, thus attempting to draw the reader as well into a more attuned understanding of African-American experience.
\end{abstract}

Keywords: James Baldwin, music, blues, migration, identity, “Sonny's Blues," France

Multi-Media: A supplementary performance by the author is available on the JBR website.*

It is only in his music [...] that the Negro in America has been able to tell his story. It is a story which otherwise has yet to be told and which no American is prepared to hear. As is the inevitable result of things unsaid, we find ourselves until today oppressed with a dangerous and reverberating silence.

James Baldwin, "Many Thousands Gone" 
All I know about music is that not many people ever really hear it. And even then, on the rare occasions when something opens within, and the music enters, what we mainly hear, or hear corroborated, are personal, private, vanishing evocations.

James Baldwin, "Sonny's Blues"

James Baldwin has got me feeling the spirit. His spirit, that is. His spirit is a force of love wedded with the desire to uncover and spread love. His is a recognition of collective and collected agonies, yet the instinct to dance on through it. Rather than a "vanishing evocation," Baldwin's spirit powers through music especially, opening me wide (and us inevitably) to the very comprehension that he fears eludes most Americans. ${ }^{1}$ But this comprehension is hard to come by, both for Baldwin and us. For Baldwin, it takes more than music, but rather a combination of music, word, and migration to really understand AfricanAmerican experience. Through the experience of what I term dislocated listening, James Baldwin continually hears and writes a tragicomic blues tale of AfricanAmerican experience. Baldwin's blues resonates even more powerfully and painfully for its emotional and geographical dislocation. What Baldwin evokes in his life, in "Sonny's Blues," and in my performance of his words is the possibility of a more attuned understanding of African-American identity.

James Baldwin's experiences of racial identity were never static; they were always in flux and in relation to his interactions with other cultures, peoples, and lands. He first fled the U.S. in 1948. Angered by race relations in the U.S., he migrated to Paris and would later settle in southern France (specifically SaintPaul-de-Vence). Yet, settle belies Baldwin's movement as he would return to the U.S. and live in Turkey as well. Even his early works crafted a dialogue between the U.S. and Europe. With his 1955 collection of critical essays, Notes of a Native Son, he interwove reflections on race and ethnicity in Europe such as "Equal in Paris" and "Stranger in the Village" with investigations of life in the U.S. like "The Harlem Ghetto" and "Journey to Atlanta." Although he shifted back and forth between the U.S. and Europe, Baldwin was forever rooted to his native Harlem, New York. He had learned through his travels that "you never leave home. You take your home with you." Still it would take the combined forces of moving away from the U.S., listening to the blues, and writing to help him best articulate what it meant to be African-American.

Retreating to the mountains of Loèche-les-Bains, Switzerland in 1953, James Baldwin took only two records. ${ }^{4}$ Originally released in 1927 on Columbia records, Bessie Smith and James P. Johnson's "Backwater Blues" was one of these. The record was most significant, because Baldwin had repeatedly avoided listening to it in the U.S. ${ }^{5}$ But as he searched for inspiration to finally finish his first novel, the semi-autobiographical work Go Tell It On the Mountain, James Baldwin listened to Bessie Smith. "It was Bessie Smith, through her tone and cadence, who helped me to dig back to the way I myself must have spoken when I was a pickaninny, and to remember the things I had heard and seen and felt. I 
had buried them very deep [...] in Europe, she helped to reconcile me to being a 'nigger."'6

I think Baldwin's experience of feeling like a "nigger" was realizing the power of word and song to echo memories of injustice and stereotype. Smith's language called up memories from his youth, ancestry, and a history of collective significations read on his and other black bodies over time. Josh Kun explains, "[Smith] was the summation of all the stereotypes, all the prejudices, all the projected racial and sexual fantasies, all the watermelons and pickaninnies and dialect speech, and all the externally imposed self-hate."7 Smith's record in all its racialized significations exemplified a history of violence and suffering that Baldwin had attempted to assuage in his exile. Reflecting on his first moments of exile, he once said, "It gave me time to vomit up a great deal, a great deal of bitterness."

The blues, in the form of Bessie Smith's persona, lyrics, and voice, were the impetus for an uncomfortable purging and recognition of his racialized history. Smith was not just any blues singer, but was nicknamed the Empress of the Blues; she was a recognizable and popular leader of the genre. Her cross-over fame was not enough, though, to open some doors. Josh Kun details how her sexy lyrics and poor upbringing in Chattanooga, Tennessee dissuaded middle class blacks, and her unpolished timbre prompted rejection from record labels; in sum, he writes that her voice was deemed "too rough, too Negro, too black."" All of these readings of Smith's blackness, from slurs to stereotypes, performed through the music for Baldwin. He was afraid to internalize and revisit these performances of race. But the blues, especially Smith's variety, had a way of laying bare the good and the bad. For Bessie Smith exemplified the unvarnished, edgy, raunchy, frank, and funny possibilities of the blues. Yet at the same time rumors about the circumstances of her death bespoke tragedy. Suffering the effects of a car crash in 1937 Mississippi, Smith was purportedly refused entry into a white hospital and died before she could get to a black hospital; though Down Beat's November 1937 report laid the blame of her death on institutionalized racism, this account has since been disproven. ${ }^{10}$ But Smith's persona still represented the tragicomic nature of the blues and inextricably of AfricanAmerican experience.

For Smith's "too rough, too Negro, too black" style and content foregrounds what Ralph Ellison calls the "jagged grain." Ellison describes the blues as "an impulse to keep the painful details and episodes of a brutal experience alive in one's aching consciousness, to finger its jagged grain, and to transcend it, not by the consolation of philosophy but by squeezing from it a near-tragic, nearcomic lyricism." ${ }^{11}$ The blues, particularly Smith's, are tragicomic because they offer a space in which the tragic merges with the comic, the heartache meets the joy, the down and out meets the trick to survive. This tragicomic quality wedded with the blues genre's privileging of timbre and mood over polish spurred a discomforting effect in Baldwin. In particular, Smith's voice was grainy, gritty, and soul stirring. As Baldwin returned to a song he'd long disavowed, the "jagged 
grain" of black music moved him; the blues opened him up and forced a visceral understanding of and confrontation with his African-American heritage-an experience I call dislocated listening.

Dislocated listening is the combination of geographical movement away from one's racial and national heritage and the expression of that same heritage through the performance of music. In this experience, geographical distance disconcerts, leaving one more vulnerable and isolated, while music prompts a visceral response and spurs a confrontation with and greater understanding of one's racial past. Dislocated listening starts with a dislocation, a separation from and/or movement away from home. In Baldwin's case this dislocation was a voluntary migration from the U.S. to Europe. In James Baldwin Now, Michelle Wright describes geographical dislocation as essential in guiding Baldwin to dismantle master narratives about racial identity and relations. Analyzing "Encounter on the Seine," in which Baldwin describes his interactions with French of African descent in Paris, Wright notes: "Through these encounters Baldwin posits the importance of transatlantic discourse in cutting through the simplistic mythologies of oppressed and oppressor pinned to the linear chronology of progress." 12 In his interactions with Algerians, for example, Baldwin was exposed to different cultures, customs and inevitably different histories and experiences of blackness. His travels complicated his conceptions of race and presented different racial and ethnic power relations with which to relate his own experiences in the U.S.

However, the separation in dislocated listening is not necessarily only geographical but could also be psychological dislocation, as in a rupture from a psychological sense of home, identification, and security. In his analysis of Baldwin's exilic oeuvre, Robert Tomlinson discusses the always already dislocated nature of all African-American identity: "For the African-American subject in particular, the voyage to a foreign land is an exile that restages the original historical and cultural alienation at 'home.' In one sense, then, the fact of geographic exile can be seen as the symbolic extension of a radical existential exile." 13 In this perspective, the habitual and historical alienation of African-Americans in the U.S. makes the African-American always a stranger. As Baldwin migrates, his foreignness becomes even more pronounced.

The geographical movement or psychological separation of dislocated listening next spurs a distancing. In the process of this distancing, one not only moves away but toward harsh realities of African-American experiences, specifically to a history of suffering. Baldwin's fear of and reconciliation with the concept of "nigger" seems wrapped up in the lack of humanity, oppression, objectification, and invisibility that gets read onto African-Americans. Finally facing his relation to such limitations of racialization causes Baldwin extreme discomfort.

Such is the next step of dislocated listening - a disorientation and discomfort that spurs vulnerability yet opens one to a new experience. For Baldwin, the primary path to this discomfort is music. Throughout his oeuvre, Baldwin has expressed the debt that is owed to music for its ability to communicate the 
stories of African-Americans. In situations where no one will listen, on issues "no American is prepared to hear," music pushes through these obstacles. ${ }^{14}$ Significantly, it is not just the universal appeals and potential heartstrings that any music can pull. No, it is black music that induces heightened awareness of racial history. Baldwin explains:

I remember, anyway, church suppers and outings, and later after I left the church, rent and waistline parties where rage and sorrow sat in the darkness and did not stir, and we ate and drank and talked and laughed and danced and forgot all about "the man." We had the liquor, the chicken, the music, and each other, and had no need to pretend to be what we were not. This is the freedom that one hears in some gospel songs, for example, and in jazz. In all jazz and especially in the blues, there is something tart and ironic, authoritative and double-edged. ${ }^{15}$

This double-edged quality of black music affirms Ralph Ellison's discussion of the blues as tragicomic. This doubled, seemingly contradictory tragicomic quality of the blues especially opens up the recipient to new thinking and feeling.

Bessie Smith is an important symbol of Baldwin's destabilized and vulnerable search for identity. He evokes her in multiple texts, not just in the aforementioned example from "The Discovery of What it Means to Be an American" and the forthcoming discussion of "Sonny's Blues." Smith also played a role in his novel, Another Country. The suicide-driven jazz musician Rufus listens to Bessie Smith. After his death, his former white American expatriate lover Eric returns from France for a job opportunity in the U.S. But in his reminiscences of the U.S., Rufus, and the love he has just left behind in France, Eric's memories and dialogues are interrupted by Bessie Smith's lyrics. One scene eerily parallels the visceral experience of dislocated listening: "For the large living room was empty, and filled with the sound of the blues. It was the voice of a colored woman, the voice of Bessie Smith, and it hurled him, with violence, into the hot center of his past: It's raining and it's storming on the sea. I feel like somebody has shipwrecked poor me." ties of who can connect with this racialized past, for even the white American character Eric can be pulled into the experience of dislocated listening. ${ }^{17}$

In the last step of dislocated listening, instead of pulling away due to discomfort, the person is prompted to engage. This deep engagement leads to a new level of understanding that takes the form of a revelation about self-identity, moreover a connectedness to the struggle for racial identity and articulation across the ages. For James Baldwin, this was the ability to better articulate his past, both individual and collective, as a writer. Baldwin's personal experience of dislocated listening realizes itself prominently on the pages of "Sonny's Blues"through the brothers' geographical dislocation, Sonny's shaky and vulnerable musical confrontation with his memories, and the history-jumping and peopleconnecting performance zone Sonny reaches in the final blues and jazz performance of the short story. 
Published in 1957, “Sonny's Blues” was written for Partisan Review while James Baldwin lived in Paris. ${ }^{18}$ But the story portrays the inability of AfricanAmerican brothers to listen to each other in mid-century Harlem. One brother, Sonny, is a pianist who struggles to escape life in Harlem by seeking out drugs, traveling in the Navy and performing jazz. The story is told by Sonny's unnamed brother and reveals a tenuous relationship between the middle class, conservative brother as a school teacher and the more experimental and rule-breaking Sonny as jazzman.

"Sonny's Blues" also illustrates multiple facets of New York City: from highlighting life in the ghetto, to pervasive drug access, to the bohemian lifestyle, to jazz clubs, and to corner churches. For Baldwin, Harlem in particular reflects a darkness in American society, in which the African-American is situated in poverty and hopelessness that is nearly inescapable. While "Sonny's Blues" does not replicate Baldwin's trans-Atlantic migration, it does emphasize the importance of geographical dislocation, starting with both brothers' exile from the Harlem ghetto. The unnamed brother literally flees the Harlem ghetto, hoping to attain more chances for success in a middle class neighborhood. Psychologically he also distances himself from Sonny-leaving him behind with his wife and family while in the military, failing to talk with Sonny, and being closed off to Sonny's profession as a jazz musician. Most importantly, the brother leaves behind the struggles of his family and of Sonny to survive; "Sonny's Blues" reveals the brother's journey to better comprehend his brother. Throughout the story, the brother flashes back to signal moments in Sonny's childhood and young adulthood. Yet, he remains closed to understanding Sonny's experiences until the climactic, culminating jazz and blues performance at the end of the story.

The short story also features Sonny's attempts at flight-from drugs, to military service, to jazz and blues. In each case, these separations from family and home further destabilize Sonny's sense of self. He wanders throughout the story in search of his identity until the final performance. As with Baldwin, the blues become Sonny's tool for understanding his racial past, both individual and collective. But Sonny plays rather than listens to the blues.

In the final pages, Sonny has been out of prison for a year, where he had finally been caught and sentenced for drug use. Sonny has been separated from his environment, from his drug habits and from his family. In this moment he is invited to return to play the blues at a club located in Harlem, the very site of his childhood and the traps he'd been running from all his life. The ghetto, like Smith's records for Baldwin, represented oppressive and limiting bounds of racialization that Sonny had hoped to escape.

As Sonny returns to the piano after a year away, the time and distance exacts a nervous response, moreover a "torment;" Baldwin writes, "Sonny moved, deep within, exactly like a person in torment [...] Sonny hadn't been near a piano for over a year. And he wasn't on much better terms with his life, not the life that stretched before him now. He and the piano stammered." 19 Sonny does not struggle with the skill level it takes to perform professionally. Nor is it a 
matter of letting go and letting the music take over. Instead, this is a moment of psychological confrontation with who he was before, who he is after his jail release, and the man and performer he wants to become. Sonny wanders through his different and seemingly separate selves, trying to find sense of everything as he plays. His struggle is a visceral experience, a feeling of discomfort and vulnerability that makes him stumble and stutter his way along.

Baldwin details the pain ravaged in his face, as the brother recounts: "And the face I saw on Sonny I'd never seen before. Everything had been burned out of it." ${ }^{20}$ But gradually as the concert progresses, the band starts to play together. And, Sonny is no longer alone and isolated, for the group has enfolded him. Together the band tells their story of African-American culture, they try "to make us listen." 21 They tell that tragicomic narrative of the blues, what Baldwin describes as "suffering" and "delight," as "fury of the battle," as "triumph." 22 The suffering is collectively performed and shared by the band, until Sonny gets another moment to solo. This time there is a transformation in Sonny and the brother as he listens. Sonny can hear how to free the brother and the band from the torment of a history of oppression, pain, and miscomprehension of AfricanAmerican expression. He can hear across history, back to his parents remembering the struggle they conveyed to him.

In this moment, Sonny's performance has the potential to also connect us as readers with his parents and his own tragic moments. "Sonny's Blues" can become a performed effigy calling back and bringing forth memories of racial oppression and persistence. In discussing the impact of "Backwater Blues" on James Baldwin, Josh Kun writes, "Records like Smith's are 'performed effigies,' audio surrogates that sound forth distant absences and conjure up distant pasts"23 In the last section of this essay, I too offer my embodied performance of "Sonny's Blues" as a surrogate, as a vessel through which one may approach the experience of dislocated listening. In Joseph Roach's discussion of performed effigies, which Kun draws from, one cannot fully embrace memory without discussing the surrogacy of it.

Such effigies are made by performances. They consist of a set of actions that hold open a place in memory into which many different people may step according to circumstances and occasions. I argue that performed effigies-those fabricated from human bodies and the associations they evoke-provide communities with a method of perpetuating themselves through specially nominated mediums or surrogates: among them, actors, dancers. ${ }^{24}$

Through an oral interpretation of "Sonny's Blues," which is available online, I attempt to capture in some way that place of cognition and connection that the experience of dislocated listening creates. ${ }^{25}$ It is my hope that through my performance you (and myself in the telling) may also approach the visceral opening up that I have described, the isolating yet connective experience of dislocated listening. As Roach suggests, performed effigies create a "place in memory into 
which many different people may step." But Baldwin and Sonny are not the only ones who can enter. ${ }^{26}$ Baldwin's words have led me to this "place in memory" too. This place containing Sonny and his parents as well as Baldwin and his memories is big enough to take my own histories and imaginings, but the "set of actions that hold open" that place wield a great power. What else but music, particularly the blues, could get even the distant reader to connect and finally hear some of the journey of African-Americans.

Thus, in my considerations of how to perform "Sonny's Blues," music is essential. It is not a recording that I choose to play in the background, but rather my own voice and gesture. I intentionally interpret the music and the description of the music Baldwin provides. For "Sonny's Blues" is a re-presentation of a moving musical experience and so is "The Discovery of What it Means to Be American." My performance provides greater access to that aural learning but there remains a tension; for the "real" sound of those recordings must still be discovered. Also, I draw on the spirit and memories these songs evoked in Baldwin and Sonny rather than the recording. In my performance, you see and hear how I evoke Baldwin's spirit and the meanings I attach to them.

I first draw on Akst and Clarke's 1929 composition "Am I Blue," which is actually mentioned in "Sonny's Blues." Baldwin writes, "and then without an instant's warning, Creole started into something else, it was almost sardonic, it was Am I Blue. And as though he commanded, Sonny began to play. Something began to happen." 27 The choice of "Am I Blue" by Baldwin is curious, given the older age of the song and its style as a popular show tune rather than a standard 12-bar blues. This song choice seems to counter Sonny's protestations earlier in the story that his jazz is not the style of Louis Armstrong, but rather the modern, critical, and non-conformist style of Charlie Parker. ${ }^{28}$ In his essay “The Jazz-Blues Motif in James Baldwin's 'Sonny's Blues,” Robert Albert ponders this strange song choice that was originally created for the musical "On with the Show" and for Ethel Waters, an African-American artist who had managed to have some cross-over success in film; Albert explains that the song may add an element of the traditional, on which the modern, improvising pianist Sonny makes his own mark. ${ }^{29}$ So "Am I Blue" becomes the medium through which the more modern Sonny connects with his brother (of more traditional leanings) and his family both alive and gone.

Rather than Waters' rendition of "Am I Blue?" I take as inspiration Billie Holiday's 1941 recording. Holiday's reign in popularity coincides with that of Sonny's musical hero, Charlie Parker. Holiday's voice taps into a mournful clarity that can potentially pierce the soul and spur a sharp visceral reaction in the listener. Her timbre and tone work well as Sonny's symbols of suffering. In his discussion of Holiday's "Lady in Satin," Fred Moten describes the tragicomic sensibility of the song as "an iterable event of joy and pain." ${ }^{30}$ Most importantly for Moten, "The lady in satin uses the crack in the voice, extremity of the instrument, willingness to fail reconfigured as a willingness to go past." ${ }^{11}$ I envision Sonny's playing in this scene as a crack in performance, wherein he fails as 
he plays yet he still persists and prevails. In my oral interpretation of "Sonny's Blues," I purposefully avoid a polished interpretation of song and reach instead for a roughness-an edgy cracking. This "crack in the voice" meets the "jagged grain," both signifying on struggle yet freedom, tragedy yet hope. In the excerpt I recite, Baldwin's words express this "crack in the voice" and "jagged grain" as Sonny stutters on the piano with pain burned in his face. Such is Sonny's visceral absorption of the tragicomic nature of African-American experience, both the harsh realities and the joys. As the music takes over and impels Sonny to passionately play on "at the risk of ruin, destruction, madness, and death," so Sonny also illustrates "how we are delighted." 32 This acknowledgement is an epiphany for the narrating brother but also Sonny. But their joyful awareness and triumph depends on the unforgettable, recurring marks of ethnic trauma.

I translate this repetition of racialized suffering with a recurring motif from the opening of "Blue Monk" by Thelonius Monk in 1954. As an inventive bop pianist with an unpredictable improvisatory approach, Monk's style immediately comes to mind as a relevant model for Sonny's stammering piano performance. As Sonny struggles on the piano, stopping and starting, so too I scat in stutters, leaving incomplete Monk's melody. At the end of my performance, the two songs come together, riffing and overlapping in order to convey the musical zenith Sonny reaches, paired with his heightened understanding of racial history and heritage. This moment of enlightenment seems only available through musical performance.

Through performance, I too return to "that place in memory" as I co-perform the tragicomic sensibility of African-American experience. For performing "Sonny's Blues" inspires what Performance Studies scholar Dwight Conquergood calls co-performative witnessing. Analyzing Frederick Douglass' description of the emotive and provocative power of slave songs, Conquergood promotes ways of knowing through personal experience and engagement with non-written texts: "Instead of reading textual accounts of slavery, Douglass recommended a riskier hermeneutics of experience, relocation, copresence, humility, and vulnerability: listening to and being touched by the protest performances of enslaved people."33 As I read and perform "Sonny's Blues," I cannot remain a distanced observer. I feel the tensions the words and music express, the discomfort and dislocation of Baldwin's spirit coming through. The performance prompts me to question my own spot, as an African-American woman, in the "long line" of ancestors Sonny recalls. ${ }^{34}$ That "long line" of survivors of the pains and triumphs of being African-American. The most awe-inspiring part of "Sonny's Blues" is that this witnessing whether through reading, hearing or embodying is not confined to African-Americans, nor to Harlem, nor to the mid-century moment of the text. Baldwin's blues sing true across geographical and historical bounds. Though not a musician, Baldwin's ear heard, his pen described, and his lingering spirit still sings through the blues. Baldwin's blues evoke feeling and music, listening and performance, individual and collective experience. His literary blues inspire and revive his individual and our shared tragicomic experience of race. They 
sing to me as I read, and through me as I perform. Listen hard and Baldwin's blues just might have you feeling the spirit too.

\section{Notes}

* The full URL for the multi-media aspect of this article is https://www.youtube.com/ watch?v=u8SWy9DETuw

1 This quote and paraphrase references the epigraphs, which also draw from the following sources: James Baldwin, "Sonny's Blues," (1957) in T. Morrison (ed.), James Baldwin: Early Novels and Stories (New York, The Library of America, 1998), p. 861; James Baldwin, "Many Thousands Gone," (1955) in Toni Morrison (ed.), James Baldwin: Collected Essays (New York, The Library of America, 1998), p. 19.

2 James Baldwin, Notes of a Native Son, (1955) in Toni Morrison (ed.), James Baldwin: Collected Essays (New York, The Library of America, 1998), pp. 1-126.

3 James Baldwin, The Price of the Ticket, directed by Karen Thorsen (San Francisco, California, Maysles Films and WNET/American Masters, 1989), VHS.

4 James Baldwin, "The Discovery of What it Means to be an American," (1961) in Toni Morrison (ed.), James Baldwin: Collected Essays (New York, The Library of America, 1998), p. 138.

5 Bessie Smith and James P. Johnson, “Backwater Blues," 17 February 1927, Columbia 14195D.

6 Baldwin, “The Discovery," p. 138.

7 Josh Kun, "Life According to the Beat," Audiotopia: Music, Race and America (Berkeley, University of California, 2005), p. 94.

8 James Baldwin, The Price.

9 Kun, "Life According to the Beat," p. 94.

10 Chris Albertson, Bessie (New Haven, Yale University Press, 2005), pp. 256-7.

11 Notably, Ralph Ellison describes this tragicomic sensibility of the blues in his discussion of the life of Richard Wright. As another African-American writer focused on American race relations and exiled in post-WWII Paris, Wright was Baldwin's unofficial mentor yet contemporary. He was also the starting point against which Baldwin critiqued and articulated African-American identity. It is interesting that Ellison's discussion of blues (as a fitting autobiographical genre for Wright's life) also applies so well to Baldwin. For more information, see Ralph Ellison, "Richard Wright's Blues," (1945) in John F. Callahan (ed.), The Collected Essays of Ralph Ellison (New York, Random House, 1995), p. 129.

12 Michelle Wright, “'Alas, Poor Richard!' Transatlantic Baldwin, the Politics of Forgetting, and the Project of Modernity," in Dwight A. McBride (ed.), James Baldwin Now (New York, New York University, 1999), p. 228.

13 Robert Tomlinson, “'Payin' One's Dues:' Expatriation as Personal Experience and Paradigm in the Works of James Baldwin," African American Review, 33:1 (1999), pp. 135-7.

14 Baldwin, "Many Thousands Gone," p. 19.

15 Baldwin, "Down at the Cross," (1963) in T. Morrison (ed.), James Baldwin: Collected Essays (New York, The Library of America, 1998), p. 311.

16 James Baldwin, Another Country, 5th edn, (New York, Vintage, 1992), p. 32.

17 In “The Jazz-Blues Motif in James Baldwin's 'Sonny's Blues,"” Robert Albert also tests the relevance of Sonny's performance to non-African-Americans. Albert suggests that Baldwin's choice of Creole, as the bandleader who plays a prominent role in leading 
Sonny to his musical and psychological epiphany, seems awry. Given the Spanish and French ancestry of Creoles in Louisiana, Albert notes that the character of Creole would be a strange guide into African-American heritage that is descended from African slaves. Albert argues that perhaps with the choice of Creole James Baldwin intentionally expands the racial composition of the transhistorical African-American community that embraces Sonny via his final musical performance. See Richard Albert, "The Jazz-Blues Motif in James Baldwin's 'Sonny's Blues,"' College Literature, 11:2 (1984), p. 181.

18 Baldwin, "Sonny's Blues," p. 861.

19 Ibid., pp. 861-2.

20 Ibid., p. 862.

$21 \mathrm{Ibid}$.

22 Ibid.

23 Josh Kun, Audiotopia, p. 94.

24 Joseph Roach, Cities of the Dead: Circum-Atlantic Performance (New York, Columbia University Press, 1996), p. 36.

25 In the online version of this article, you can access audiovisual clips of my oral interpretation of Sonny's finale performance.

26 In Teju Cole's recent New Yorker article in honor of the 100th anniversary of James Baldwin's birth, Cole shares his own experience of geographical dislocation and racial identification with Baldwin. Cole revisits Baldwin's essay "Stranger in the Village" in its Swiss home of composition, Loèche-les-Bains (the same site as Baldwin's prominent experience of dislocated listening through Bessie Smith's records). Cole's feeling of identification and doubling with Baldwin parallel some of the aspects of dislocated listening, and his account offers another interesting example. See Teju Cole, "Black Body: Rereading James Baldwin's 'Stranger in the Village,"' The New Yorker, 19 August 2014, http://www.newyorker.com/books/page-turner/black-body-re-reading-jamesbaldwins-stranger-village (accessed 31 March 2015).

27 Baldwin, "Sonny's Blues," p. 862.

28 Ibid., pp. 846-7.

29 Albert, "The Jazz-Blues Motif," p. 184.

30 Fred Moten, In The Break: The Aesthetics Of The Black Radical Tradition (Minneapolis, University of Minnesota Press, 2003), p. 107.

31 Ibid.

32 Baldwin, “Sonny's Blues,” p. 862.

33 Dwight Conquergood, "Performance Studies: Interventions and Radical Research," The Drama Review, 46:2 (2002), p. 150.

34 Baldwin, "Sonny's Blues," p. 862.

\section{Works Cited}

Albert, Richard, “The Jazz-Blues Motif in James Baldwin's 'Sonny's Blues,"” College Literature, 11:2 (1984), pp. 178-85.

Albertson, Chris, Bessie (New Haven, Yale University Press, 2005).

Baldwin, James, The Price of the Ticket, Directed by Thorsen, Karen (San Francisco, California, Maysles Films and WNET/American Masters, 1989). VHS. Another Country, 5th edn., (New York, Vintage, 1992). 
"Down at the Cross," (1963) in Toni Morrison (ed.), James Baldwin: Collected Essays (New York, The Library of America, 1998), pp. 296-348.

"Many Thousands Gone," (1955) in Toni Morrison (ed.), James Baldwin: Collected Essays (New York, The Library of America, 1998), pp. 19-34.

"Notes of a Native Son," (1955) in Toni Morrison (ed.), James Baldwin: Collected

Essays (New York, The Library of America, 1998), pp. 1-126.

"Sonny's Blues," (1957) in Toni Morrison (ed.), James Baldwin: Early Novels and Stories (New York, The Library of America, 1998), pp. 831-64.

"Stranger in the Village," (1955) in Toni Morrison (ed.), James Baldwin: Collected Essays (New York, The Library of America, 1998), pp. 117-36.

"The Discovery of What it Means to be an American," (1961) in Toni Morrison (ed.), James Baldwin: Collected Essays (New York, The Library of America, 1998), pp. 137-42.

Cole, Teju, "Black Body: Rereading James Baldwin's 'Stranger in the Village," The New Yorker, 19 August 2014, http://www.newyorker.com/books/page-turner/black-bodyre-reading-james-baldwins-stranger-village (accessed 31 March 2015).

Conquergood, Dwight, "Performance Studies: Interventions and Radical Research," The Drama Review, 46:2 (2002), pp. 145-56.

Ellison, Ralph, "Richard Wright's Blues," (1945) in John F. Callahan (ed.), The Collected Essays of Ralph Ellison (New York, Random House, 1995), pp. 128-44.

Holiday, Billie, “Am I Blue,” Am I Blue, 9 May 1941, Columbia, Columbia 37586.

__ "Solitude," Songs by Billie Holiday, 26 March 1952, Clef MGC 690.

"Lady in Satin," Lady in Satin, 19-21 February 1958, Columbia CL 1157.

Kun, Josh, "Life According to the Beat," in Audiotopia: Music, Race and America (Berkeley, University of California, 2005), pp. 86-112.

Monk, Thelonius, "Blue Monk," 22 September 1954, Thelonius Monk Trio. Prestige PRLP 7027.

Moten, Fred, In The Break: The Aesthetics Of The Black Radical Tradition (Minneapolis, University of Minnesota Press, 2003).

Roach, Joseph, Cities of the Dead: Circum-Atlantic Performance (New York, Columbia University Press, 1996).

Smith, Bessie and Johnson, James P., "Backwater Blues," 17 February 1927, Columbia 14195D.

Tomlinson, Robert, “Payin' One's Dues:' Expatriation as Personal Experience and Paradigm in the Works of James Baldwin," African American Review, 33:1 (1999), pp. 135-48.

Wright, Michelle M., ““Alas, Poor Richard!” Transatlantic Baldwin, the Politics of Forgetting, and the Project of Modernity," in Dwight A. Mcbride (ed.), James Baldwin Now (New York, New York University, 1999), pp. 208-32.

\section{Contributor's Biography}

Rashida K. Braggs is an Assistant Professor in Africana Studies at Williams College. Throughout her work in such journals as Nottingham French Studies, The Journal of Popular Music and her forthcoming book Jazz Diasporas: Race, Music and Migration in Post-World War II Paris (University of California Press), Braggs consistently draws on her background in Performance Studies to apply a performative lens to African diasporic cultural expressions like music, literature, and art. 